\title{
Control of industrial exposure to tetrachloroethylene by measuring alveolar concentrations: theoretical approach using a mathematical model
}

\author{
E. GUBERAN and J. FERNANDEZ
}

Occupational Health and Industrial Hygiene Service, Chemistry Department of the University of Neuchâtel, Bellevaux 51, 2000 Neuchâtel, Switzerland

\begin{abstract}
Guberan, E. and Fernandez, J. (1974). British Journal of Industrial Medicine, 31, 159-167. Control of industrial exposure to tetrachloroethylene by measuring alveolar concentrations: theoretical approach using a mathematical model. The uptake, distribution, and elimination of tetrachloroethylene were studied using a mathematical model, and predicted alveolar concentrations were compared with experimental data. Because of its high fat solubility the solvent accumulated in adipose tissue with a predicted biological half-life of 71.5 hours. The relation between the alveolar concentrations and the level or duration of exposure was discussed. The alveolar concentrations of tetrachloroethylene during and after similar exposure were predicted in subjects who differed in age, body weight, height, and body fat content, both at rest and during physical effort. Predictions were made of the alveolar concentrations following exposures to steady and variable concentrations in ambient air, and following exposures of several weeks of the type occurring in industry. It was concluded that measurement of the postexposure alveolar concentrations could be used to estimate the mean exposure to tetrachloroethylene in most industrial situations.
\end{abstract}

As a result of previous studies of several industrial solvents (Riley, Fassett, and Sutton, 1966; Stewart, Baretta, Dodd and Torkelson, 1970; Stewart, Dodd, Gay, and Erley, 1970; Reinhardt, McLaughlin, Maxfield, Mullin, and Smith, 1971;Azar, Reinhardt, Maxfield, Smith, and Mullin, 1972; Di Vincenzo, Yanno, and Astill, 1972; Hunter and Blair, 1972; Sherwood, 1972) and our study of tetrachloroethylene (Fernandez and Guberan, 1974), the question arose as to whether alveolar air measurements could be used to control industrial exposure.

In this paper a mathematical model has been developed to predict uptake and distribution of tetrachloroethylene in the body and its elimination in the alveolar air. Various situations likely to arise in industry have been simulated.

\section{Physiological parameters}

In order to be able to compare measured and predicted results, the mean values of our 25 experimental subjects (Fernandez and Guberan, 1974) for age, body weight, and height were taken as the values of a standard man (Table 1). His cardiac output, blood volume, respiratory frequency, and functional residual capacity were calculated from the tables in the literature (Brandfonbrener, Landowne, and Shock, 1955; Sjöstrand, 1962; Cotes, $1965)$, and the ventilation-perfusion ratio was assumed to be 1 .

\section{Tissue groups}

Body tissues were grouped according to Eger (1963a) into four compartments-the vessel-rich group (VRG) (corresponding to brain, heart, hepatoportal system, 
TABLE 1

Physiological Parameters

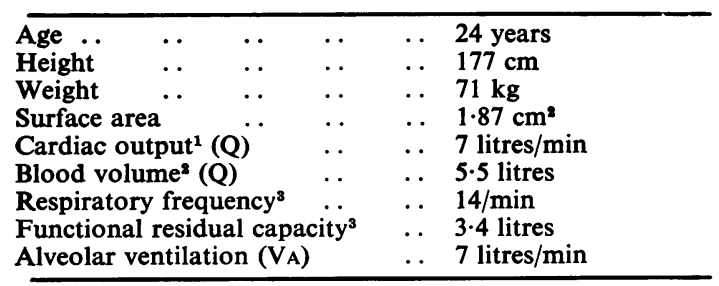

'Brandfonbrener et al. (1955)

'Sjöstrand (1962)

${ }^{8}$ Cotes (1965)

kidneys, and endocrine glands), the muscle group (MG) (muscle and skin), the fat group (FG) (adipose tissue and yellow marrow), and the vessel-poor group (VPG) composed of the connective tissue (bone, cartilage, ligaments, etc.), and also the lung tissue, with a volume of 0.5 litre. The volume and perfusion of each tissue group are given in Table 2.

\section{Partition coefficients}

The blood-gas partition coefficient of tetrachloroethylene is about 9 (Morgan, Black, and Belcher, 1970). Its oilblood coefficient is unknown but probably close to that of trichloroethylene, which is 107 (oil-gas coefficient 960 (Mapleson, 1963)) and average blood-gas coefficient about 9 (Morgan et al., 1970; Mapleson, 1963). We have no data on the other tissue-blood partition coefficients and it was assumed that they approach those given by Eger (1963a) for the highly fat soluble halothane which are respectively $2 \cdot 5,3.5$, and 1.0 for the VRG, the MG, and the VPG.

\section{Quantitative analysis}

The above data were used in the mathematical model the equations of which are given in the Appendix. A program to solve this system of equations was written in Fortran IV. Biotransformation of tetrachloroethylene is only of the order of $2 \%$ (Daniel, 1963; Ogata, Takatsuka, and Tomokuni, 1971) and was therefore neglected.

\section{Results and discussion}

Uptake and elimination by the tissue groups

As can be seen in Fig. 1, predicted uptake of tetrachloroethylene by the tissue groups is related to their perfusion rate (Table 2). In the VRG $(75 \%$ of the cardiac output) peak uptake rate occurs in the first minutes and uptake falls to a negligible level after about 60 minutes. This corresponds to the time necessary to saturate this group of tissues (when the partial pressure or tension in the tissues equilibrates with that in the arterial blood, as shown in Fig. 2). For the less perfused MG and VPG, peak uptake rate is reached after about $\mathbf{3 0}$ minutes, and equilibrium between tissue and arterial tensions does not occur within 8 hours. In the fatty tissue, because of its high tissue-blood partition coefficient, the increase of uptake rate is slower and the level of tension much lower than in other tissues.

During elimination an inverse scheme occurs with a rapid depletion of the VRG, a slower one for the MG and the VPG, and a very slow release of solvent

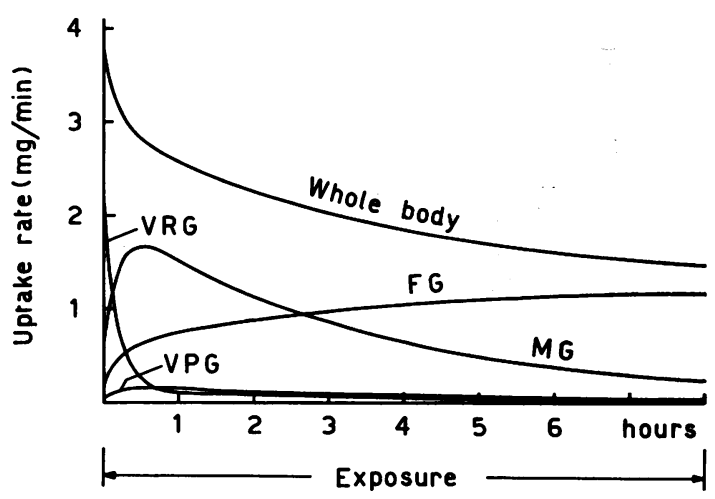

FIG. 1. Predicted uptake rate of tetrachloroethylene by the tissue groups and the whole body during 8 hours' exposure to $100 \mathrm{ppm}$.

TABLE 2

Volume, Perfusion, and Partition Coefficient of the Four Tissue Groups

\begin{tabular}{|c|c|c|c|c|c|c|c|}
\hline & & & & \multicolumn{4}{|c|}{ Tissue group } \\
\hline & & & & $V R G$ & $M G$ & $F G$ & $V P G$ \\
\hline $\begin{array}{l}\text { Volume in a } 70-k g \text { man (litres) } \\
\% \text { cardiac output to tissue group } \\
\text { Litres/min perfusion in a } 70-k g \text { man } \\
\text { Tissue-blood partition coefficient }\end{array}$ & $\begin{array}{l}\cdots \\
\text { with } 71 \mathrm{i} \\
\ldots\end{array}$ & $\begin{array}{l}\ldots \\
\ldots \\
\ldots\end{array}$ & $\begin{array}{ccc}\ldots & \ldots & \ldots \\
\text { in cardiac output } \\
\ldots & \ldots & \ldots\end{array}$ & $\begin{array}{c}6 \cdot 0 \\
75 \cdot 0 \\
5 \cdot 25 \\
2 \cdot 50\end{array}$ & $\begin{array}{c}33 \cdot 0 \\
18 \cdot 1 \\
1 \cdot 27 \\
3 \cdot 50\end{array}$ & $\begin{array}{r}14 \cdot 5 \\
5 \cdot 4 \\
0 \cdot 38 \\
107 \cdot 00\end{array}$ & $\begin{array}{c}12 \cdot 5 \\
1 \cdot 5 \\
0 \cdot 10 \\
1 \cdot 00\end{array}$ \\
\hline
\end{tabular}

${ }^{1}$ Eger (1963a) 
from the FG, starting only 8 hours after the end of exposure.

From the whole body uptake rate curve of Fig. 1 the retention $v$ time can be calculated since the weight of tetrachloroethylene inspired per minute is $4 \cdot 1 \mathrm{mg}$. Initial retention is high $(91 \%)$ and decreases to $36 \%$ at the end of the 8 hours. During the whole period the retention is $48 \%$.

\section{Alveolar partial pressure curve}

During exposure, the alveolar tension curve of tetrachloroethylene has three distinct phases-a rapid initial rise (first 20 minutes), an inflection (20-60 minutes), and a progressively slow rise towards the constant tension in ambient air (Fig. 2). Similar phases are observed for any inert gas inspired at a constant tension, differences in the duration of the phases being related to the blood and tissue solubility peculiar to each gas (Kety, 1951).

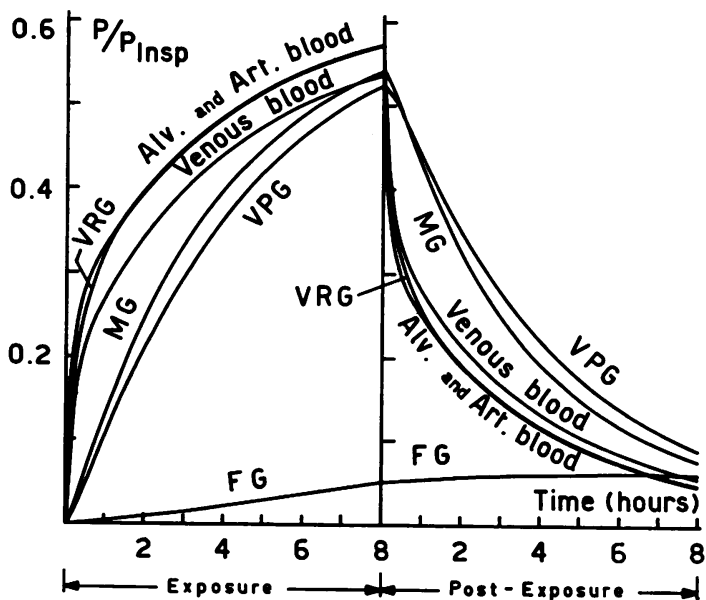

FIG. 2. Predicted partial pressure of tetrachloroethylene in alveolar air, mixed venous blood, and tissue groups during and after 8 hours of steady exposure.

Partial pressures in alveoli, blood, and tissues $(P)$ is expressed as a fraction of the constant partial pressure in ambient air during exposure ( $\left.P_{\text {Insp }}\right)$.

These phases are related to the exchanges of the solvent occurring simultaneously in the body (a) between ambient air and alveolar gas, $(b)$ between alveolar gas and pulmonary blood, and $(c)$ between peripheral blood and tissue groups. The first phase corresponds to a high uptake rate for exchanges $(a),(b)$, and $(c)$, the respective tension gradients being high. As the VRG becomes saturated, venous tension rises rapidly with a corresponding decrease of alveolar-venous tension gradient and a rapid rise of alveolar tension. The inflection of the curve (second phase) corresponds to the final phase of the VRG saturation. During the third phase the progressively low increase of alveolar tension is related to the lower respective tension gradients and therefore the lower uptake rates for exchanges $(a),(b)$, and $(c)$.

During elimination the same three phases occur with the fall of alveolar tension and would give the mirror image of the alveolar curve during uptake if complete saturation had occurred.

\section{Biological half-life}

The actual distribution of the solvent to the tissue groups during and after 8 hours of exposure to 100 $\mathrm{ppm}$ is shown in Figure 3. At the end of exposure half of the solvent taken up by the body has been distributed to the fatty tissue, due to its high tissueblood partition coefficient and despite its still low tissue tension. The respective distribution of the solvent to the other tissue groups is related to their volume and partition coefficient and therefore is higher for the MG than for the VRG and the VPG. After exposure, the depletion of these three groups of tissues is almost complete after about 20 hours and the ensuing elimination in alveolar air is related to the slow release of solvent from adipose tissue. Beyond about 20 hours of elimination the rate of discharge of the tetrachloroethylene from the adipose tissue and therefore from the whole body is an exponential function of time, predicted biological half-life being 71.5 hours.

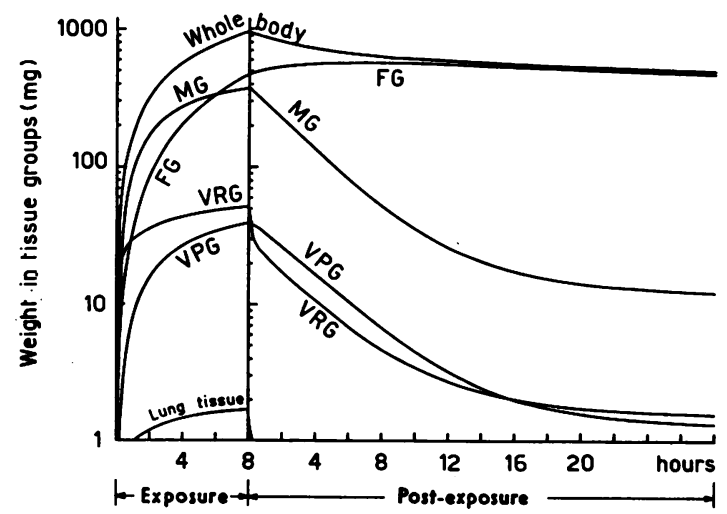

FIG. 3. Predicted distribution of tetrachloroethylene to the tissue groups during and after 8 hours' exposure to $100 \mathrm{ppm}$.

\section{Level and duration of exposure}

Alveolar concentration (as well as partial pressure) $v$ time is proportional to the level of exposure since, according to Kety (1951), the shape of the curve 
of alveolar saturation and desaturation of an inert gas is independent of the constant inspired concentration.

This law no longer applies to higher inspired concentrations than those usually met in industry, as shown by Eger (1963b) for anaesthetic gases. As we have seen, alveolar concentration is not proportional to the duration of exposure since its rise is much more rapid during the first phase of uptake. This is of practical importance since, in industrial hygiene control, level and duration of exposure have apparently the same 'weight.' In fact, the total quantity of tetrachloroethylene taken up by a continuous monitoring instrument will be the same for exposures of 8 hours to $50 \mathrm{ppm}$ or of 4 hours to $100 \mathrm{ppm}$. But this does not correspond to the same quantity of solvent penetrating the body as 3 hours 15 minutes are sufficient to reach half of the whole body uptake during 8 hours (Fig. 3). In addition, if the tetrachloroethylene concentration in the brain and other organs such as liver and heart (the VRG) is responsible for the symptoms of poisoning, it should be noted that the concentration in the VRG after 34 minutes of exposure is already half that reached in 8 hours (Fig. 2).

\section{Comparison with experimental data}

The accuracy of the many mathematical models used to predict uptake and distribution of various anaesthetics has been recently discussed by Cowles,

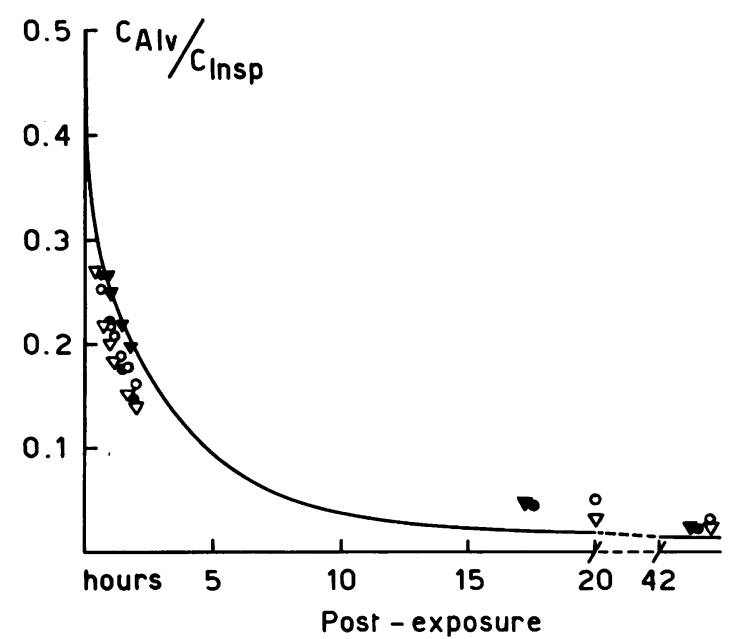

FIG. 4. Alveolar concentrations of tetrachloroethylene after 8 hours of steady exposure. Comparison of the computed curve of a standard man and the experimental data of four subjects.

Alveolar concentrations $\left(\mathrm{C}_{\mathrm{Alv}}\right)$ are expressed as a fraction of the constant concentration in ambient air during exposure ( $\left.C_{\text {Insp }}\right)$.

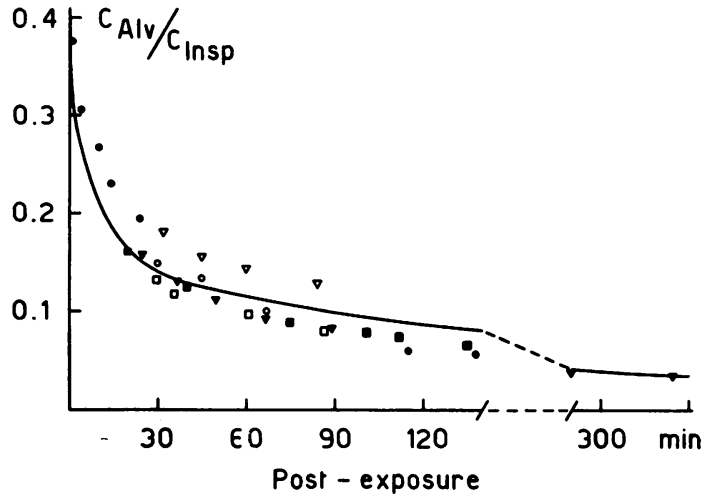

FIG. 5. Alveolar concentrations of tetrachloroethylene after 2 hours of steady exposure. Comparison of the computed curve of a standard man and the experimental data (Fernandez and Guberan, 1974) of six subjects.

Borgstedt, and Gillies (1972). In our model, we had to assume that the tissue-blood partition coefficient for adipose tissue was the same as that for trichloroethylene. For the other tissue groups we chose the most probable partition coefficient. Our results (Figs 4 and 5) show that the computed curves described hereafter are of the same order of magnitude as the real ones.

\section{Repeated exposure}

In industry, exposure often occurs Monday to Friday, 4 hours in the morning ( 8 to 12 am) and 4 hours in the afternoon ( 1 to $5 \mathrm{pm})$. Due to the incomplete elimination of the solvent from fatty tissue during the night (other tissues being almost depleted during this period) the alveolar concentration curve shows a slight daily increase during the week (Fig. 6).

When such exposure is repeated during several weeks, the uptake by fatty tissue during the working hours of the week will equal the elimination during the nights and the weekend from the fourth week on. Then, the Monday to Friday 8 am partial pressure in fatty tissue will vary from $15 \%$ to $23 \%$ of the constant partial pressure in ambient air, and the partial pressure in alveolar air from $5 \%$ to $8 \%$ (Fig. 7). This is the case for all of the following weeks of the year (Table 3). For an industrial exposure to a constant concentration of $100 \mathrm{ppm}$ the range of predicted concentrations is $96 \mathrm{mg}$ to $168 \mathrm{mg}$ of tetrachloroethylene per litre of fatty tissue from Monday morning to Friday evening, from the fourth week on.

During a three-week holiday the fatty tissue and therefore the whole body depletion will be almost complete since the biological half-life of tetrachlorothylene is about three days for this tissue. 


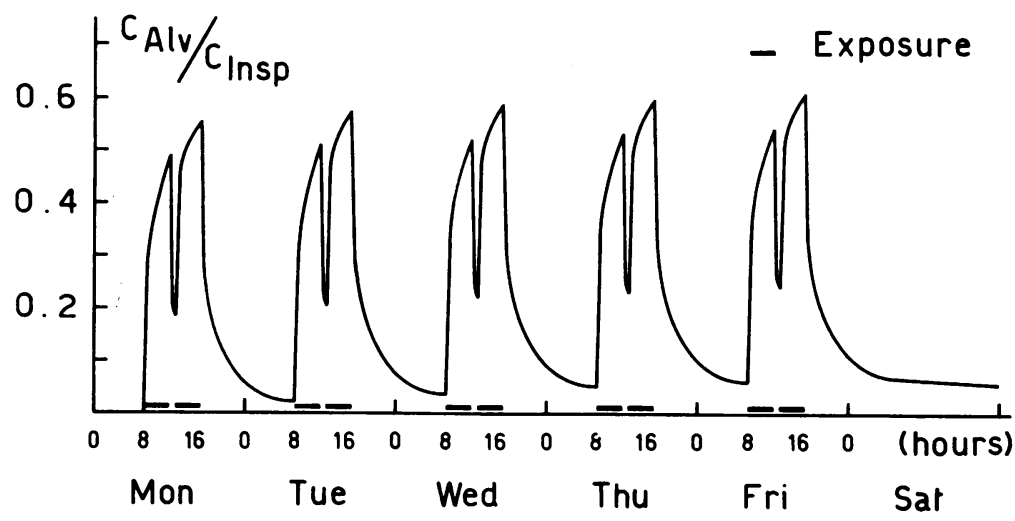

FIG. 6. Predicted alveolar concentrations of tetrachloroethylene for an 'industrial' exposure of one week. Exposure time 8-12 an and 1-5 pm, Monday to Friday.

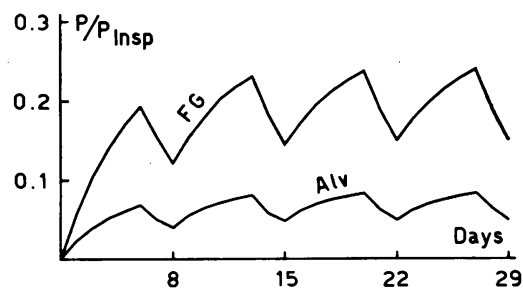

FIG. 7. Predicted partial pressures of tetrachloroethylene at 8 am in fatty tissue and alveolar air for an 'industrial' exposure of four weeks.

Exposure time 8-12 am and 1-5 pm, Monday to Friday.

Differences in body weight, height, and age

Computed curves of alveolar concentration for subjects of different age, body weight, and height, and with similar exposure, are shown in Figure 8. Other physiological parameters were calculated as for our standard man. Alveolar concentrations are slightly affected by the differences in body weight and height, as can be expected, since not only ventilation but other parameters such as cardiac output, volume of tissue groups, and blood volume are also different. The decrease of cardiac output (Brandfonbrener et al., 1955) and ventilation with age lowers alveolar concentrations to a slightly greater extent. Nevertheless, even the addition of both factors has a negligible influence on the postexposure alveolar curve of the solvent.

\section{Physical effort}

The effect of doubling the ventilation in the same subject during a physical effort is shown in Figure 9. For the 14 litres/min of alveolar ventilation, the cardiac output was assumed to be 11 litres/min (Asmussen, 1965) and the frequency of respiration $18 /$ min (Cotes, 1965). If the higher ventilation continues during the postexposure period the higher uptake is compensated by a faster elimination and both postexposure curves differ slightly.

\section{Obesity}

If our standard man was obese so that he had a double volume of fatty tissue (29 litres), his body weight would be about $85 \mathrm{~kg}$. The physiological

TABLE 3

Predicted Postexposure Alveolar Concentrations of Tetrachloroethylene as a Fraction of the Constant Concentration in Ambient Air $\left(\mathbf{C}_{\text {alv }} / \mathbf{C}_{\text {Insp }}\right)$ for Different Days of the Week (Exposure time 8-12 am and 1-5 pm, Monday to Friday; values apply to the fourth and the following weeks of exposure.)

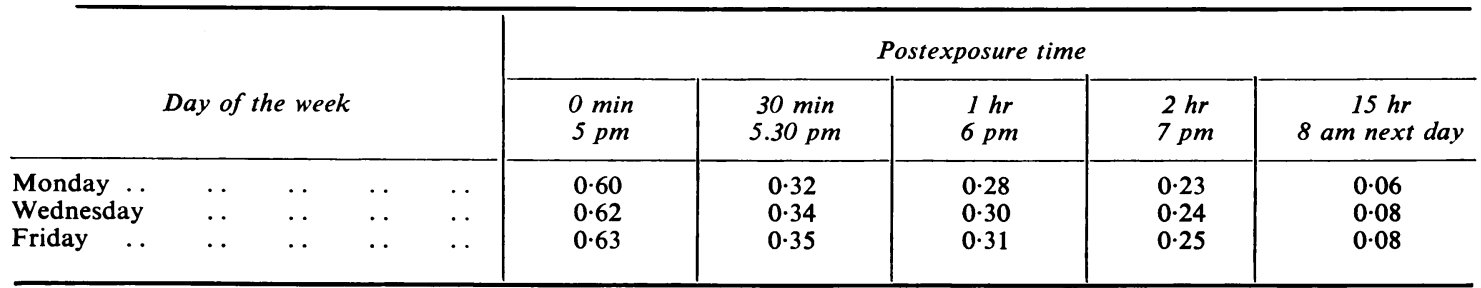




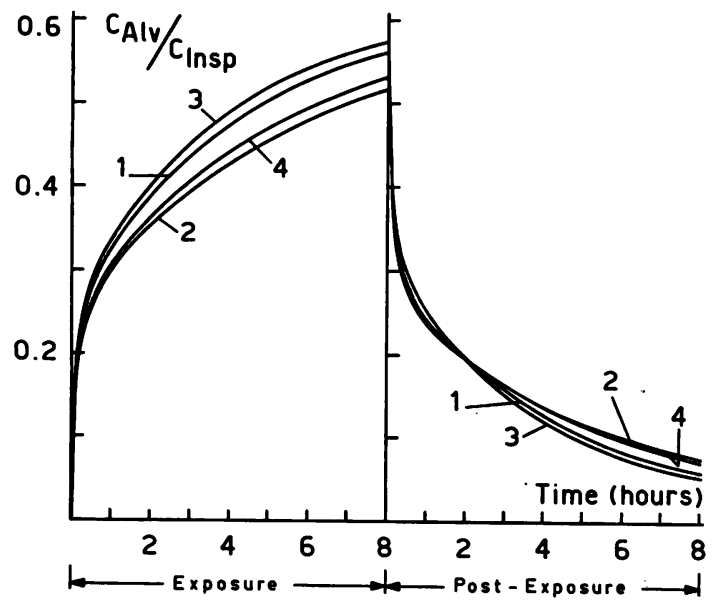

\begin{tabular}{|c|c|c|c|c|c|c|}
\hline Subject & $\begin{array}{c}\text { Age } \\
\text { (years) }\end{array}$ & $\begin{array}{c}\text { Weight } \\
(\mathrm{kg})\end{array}$ & $\begin{array}{l}\text { Height } \\
(\mathrm{cm})\end{array}$ & $\begin{array}{c}\mathrm{Q} \text { and } \\
\dot{\mathrm{V}}_{\mathrm{A}} \\
(\mathrm{l} / \text { min })\end{array}$ & $\begin{array}{c}\mathbf{Q} \\
(l .)\end{array}$ & $\begin{array}{c}\mathbf{f} \\
(N / \\
\text { min })\end{array}$ \\
\hline 1 & 25 & 85 & 185 & $7 \cdot 77$ & 6.6 & 14 \\
\hline 2 & 65 & 85 & 185 & $5 \cdot 39$ & $6 \cdot 6$ & 13 \\
\hline 3 & 25 & 55 & 155 & 5.65 & $4 \cdot 3$ & 13 \\
\hline 4 & 65 & 55 & 155 & 3.92 & $4 \cdot 3$ & 12 \\
\hline
\end{tabular}

FIG. 8. Predicted alveolar concentrations of tetrachloroethylene for four subjects of different age, body weight, and height.

parameters were calculated for that body weight in the same manner as before. Since more blood would be drained to the fatty tissue, the percentage of the cardiac output to tissues was estimated to be $71 \cdot 1 \%$, $17.2 \%, 10.3 \%$, and $1.4 \%$ for the VRG, MG, FG, and VPG respectively. As expected, obesity will lower the alveolar concentrations during uptake but slow down the elimination. Nevertheless, as shown in Fig. 10, differences of alveolar concentration during elimination between normal and obese subjects are relatively small.

\section{Variation of inspired concentration}

Figure 11 shows computed curves of alveolar concentration for an exposure which alternates hourly between $50 \mathrm{ppm}$ and $150 \mathrm{ppm}$, or between $150 \mathrm{ppm}$ and $50 \mathrm{ppm}$ during 8 hours, and that for a steady exposure to $100 \mathrm{ppm}$ for the same period. Mean exposure being the same, the hourly variations have little influence on the postexposure curve. However, this result does not apply to conditions where the concentrations fluctuate too much during exposure. In that case, the postexposure alveolar concentrations might be more influenced by the concentration in ambient air during the last period of exposure than by the mean exposure.
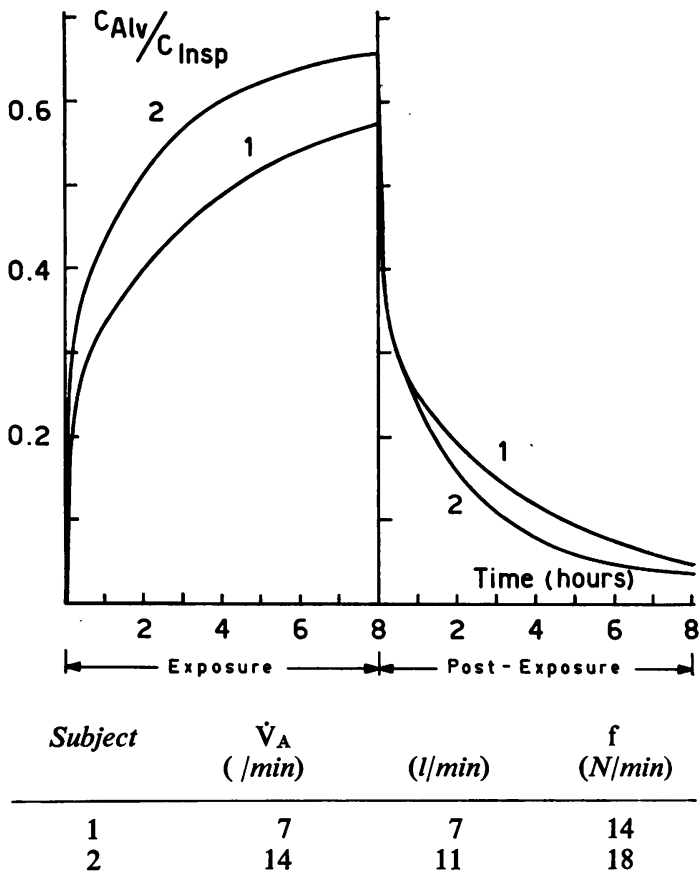

FIG. 9. Predicted alveolar concentrations of tetrachloroethylene for a standard man at rest (1) and when doubling his ventilation during a physical effort (2).

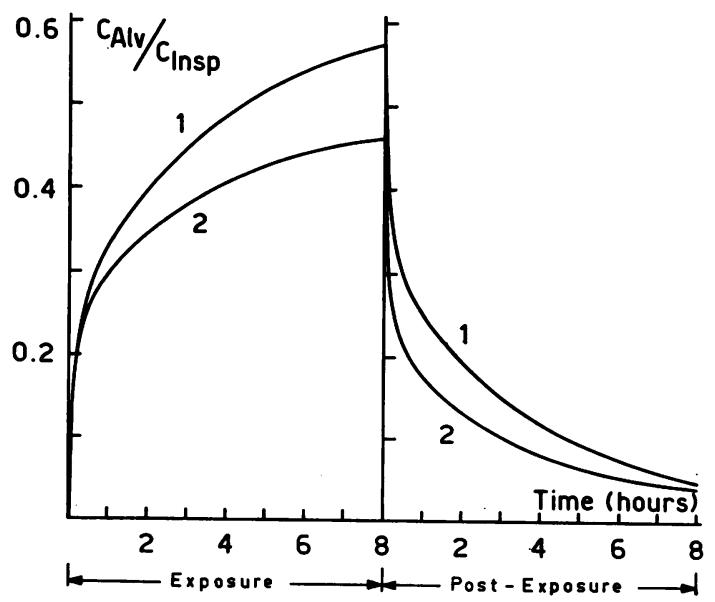

\begin{tabular}{cccccc} 
Subject & $\begin{array}{c}\text { Weight } \\
(\mathrm{kg})\end{array}$ & $\begin{array}{c}\text { Height } \\
(\mathrm{cm})\end{array}$ & $\begin{array}{c}F G \\
\text { volume } \\
(l .)\end{array}$ & $\begin{array}{c}\text { Q and } \\
\dot{\mathrm{V}}_{\mathrm{A}} \\
(l / \text { min })\end{array}$ & $\begin{array}{c}\mathrm{f} \\
(N / \text { min })\end{array}$ \\
\hline 1 & 71 & 177 & $14 \cdot 5$ & $7 \cdot 0$ & 14 \\
2 & 85 & 177 & $29 \cdot 0$ & $7 \cdot 4$ & 14
\end{tabular}

FIG. 10. Predicted alveolar concentrations of tetrachloroethylene for a standard (1) and an obese (2) man. 


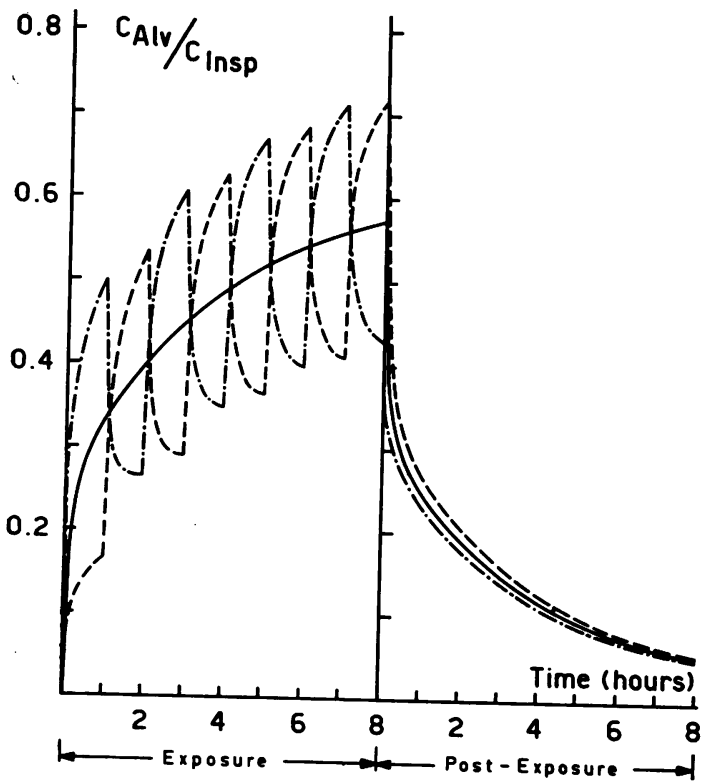

FIG. 11. Predicted alveolar concentrations of tetrachloroethylene for a standard man exposed to variable or steady concentrations in ambient air. Alveolar concentrations $\left(\mathrm{C}_{\mathrm{Alv}}\right)$ are expressed as a fraction of the mean concentration in ambient air during exposure $\left(\mathrm{C}_{\text {Insp }}\right)$. $8 \mathrm{hr}$ to $100 \mathrm{ppm}$; - _ - alternatively $1 \mathrm{hr}$ to $50 \mathrm{ppm}, 1 \mathrm{hr}$ to $150 \mathrm{ppm}$; - - - - - - - - alternatively $1 \mathrm{hr}$ to $150 \mathrm{ppm}, 1 \mathrm{hr}$ to $50 \mathrm{ppm}$.

\section{Comment}

Our results show that interindividual differences in age, body weight, height, body fat content, and physical effort, as well as moderate fluctuations around the mean concentration of tetrachloroethylene in ambient air, have an almost negligible influence on the predicted postexposure alveolar curve of this solvent. This curve shows a slight daily increase during the week following industrial exposures for $\mathbf{8}$ hours daily, Monday to Friday. In view of these findings the measurement of postexposure alveolar concentrations can be used to give a reliable estimate of the mean exposure, as shown in Figure 12. We believe that such a method could be widely applied in controlling exposure to tetrachloroethylene and to other inert vapours and gases in industry, provided the concentrations in ambient air do not vary too much during exposure.

Use of graph (Fig. 12): First measure the actual alveolar concentration of tetrachloroethylene, determine the duration of exposure and the time of measurement from the beginning of the postexposure period. Then start with exposure duration on the horizontal axis. Follow a vertical line to the postexposure time curve and from this point, along a horizontal line, find on the left the ratio $\mathrm{C}_{\mathrm{AlV}} / \mathrm{C}_{\text {Insp. }}$ This is the ratio of the actual alveolar concentration to the mean concentration of tetrachloroethylene in the ambient air to which the subject was exposed.

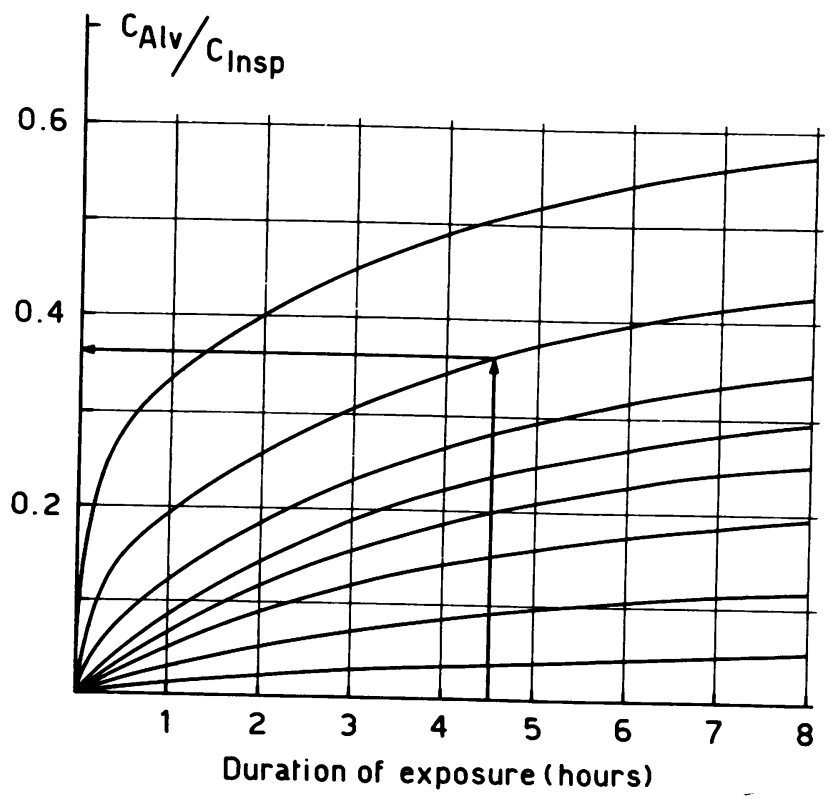

$0 \min$

$5 \mathrm{~min}$

$15 \mathrm{~min}$

$30 \mathrm{~min}$

$1 \mathrm{~h}$

$2 \mathrm{~h}$

$4 h$

$8 h$
FIG. 12. Predicted postexposure alveolar concentrations of tetrachloroethylene at various times, against duration of exposure. Alveolar concentrations $\left(\mathrm{C}_{\mathrm{Alv}}\right)$ are expressed as a fraction of the mean concentration in ambient air during exposure (CInsp).

See paragraph above. 
We are grateful to the Fonds National Suisse pour la Recherche Scientifique for financial support and to Professor F. Gendre of the Institute of Applied Psychology of Lausanne University, Switzerland for help in computation.

\section{References.}

Asmussen, E. (1965). Muscular exercise. In Handbook of Physiology, Section 3, edited by W. O. Fenn and H. Rahn, Vol. II, pp. 939-978. American Physiological Society, Washington.

Azar, A., Reinhardt, C. F., Maxfield, M. E., Smith, P. E., and Mullin, L. S. (1972). Experimental human exposures to fluorocarbon 12 (dichlorodifluoromethane). American Industrial Hygiene Association Journal, 33, 207-216.

Brandfonbrener, M., Landowne, M., and Shock, N. W. (1955). Changes in cardiac output with age. Circulation, 12, 557-566.

Cotes, J. E. (1965). Lung Function, pp. 279 and 345. Davis, Philadelphia.

Cowles, A. L., Borgstedt, H. H., and Gillies, A. J. (1972). The uptake and distribution of four inhalation anesthetics in dogs. Anesthesiology, 36, 558-570.

Daniel, J. W. (1963). The metabolism of ${ }^{36} \mathrm{Cl}$-labelled trichloroethylene and tetrachloroethylene in the rat. Biochemical Pharmacology, 12, 795-802.

Di Vincenzo, G. D., Yanno, F. J., and Astill, B. D. (1972). Human and canine exposures to methylene chloride vapor. American Industrial Hygiene Association Journal, 33, 125-135.

Eger, E. I. (II) (1963a). A mathematical model of uptake and distribution. In Uptake and Distribution of Anesthetic Agents, edited by E. M. Papper and R. J. Kitz, pp. 7287. McGraw-Hill, New York.

- (1963b). Applications of a mathematical model of gas uptake. In Uptake and Distribution of Anesthetic Agents, edited by E. M. Papper and R. J. Kitz, pp. 88-103. McGraw-Hill, New York.

Fernandez, J. and Guberan, E. (1974). Experimental human exposures to tetrachloroethylene vapour. Elimination in breath after inhalation. (In preparation).

Hunter, C. G. and Blair, D. (1972). Benzene: pharmacokinetic studies in man. Annals of Occupational Hygiene. 15, 193-201.

Kety, S. S. (1951). The theory and applications of the exchange of inert gas at the lungs and tissues. Pharmacological Reviews, 3, 1-41.

Mapleson, W. W. (1963). An electric analogue for uptake and exchange of inert gases and other agents. Journal of Applied Physiology, 18, 197-204.

Morgan, A., Black, A., and Belcher, D. R. (1970). The excretion in breath of some aliphatic halogenated hydrocarbons following administration by inhalation. Annals of Occupational Hygiene, 13, 219-233.

Ogata, M., Takatsuka, Y., and Tomokuni, K. (1971). Excretion of organic chlorine compounds in the urine of persons exposed to vapours of trichloroethylene and tetrachloroethylene. British Journal of Industrial Medicine, 28, 386-391.

Reinhardt, C. F., McLaughlin, M., Maxfield, M. E., Mullin, L. S., and Smith, P. E. (1971). Human exposures to fluorocarbon 113. American Industrial Hygiene Association Journal, 32, 143-152.

Riley, E. C., Fassett, D. W., and Sutton, W. L. (1966). Methylene chloride vapor in expired air of human subjects. American Industrial Hygiene Association Journal, 27, 341-348.

Sherwood, R. J. (1972). Evaluation of exposure to benzene vapour during the loading of petrol. British Journal of Industrial Medicine, 29, 65-69.
Sjöstrand, T. (1962). Blood volume. In Handbook of Physiology, Section 2, edited by W. F. Hamilton, Vol. I, pp. 51-62. American Physiological Society, Washington.

Stewart, R. D., Baretta, E. D., Dodd, H. C., and Torkelson, T. R. (1970). Experimental human exposure to tetrachloroethylene. Archives of Environmental Health, 20, 224-229.

—, Dodd, H. C., Gay, H. H., and Erley, D. S. (1970). Experimental human exposure to trichloroethylene. Archives of Environmental Health, 20, 64-71.

\section{APPENDIX}

\section{Mathematical model}

During each respiratory cycle (the duration of which is dt) exchange of solvent occurs until the state of equilibrium is reached:

I between compartment $1=$ alveolar gas, and compartment 2 = pulmonary blood + lung tissue II between compartment $1^{\prime}=$ peripheral blood, and compartment $2^{\prime}=$ body tissues (divided in four tissue groups).

According to Henry's law, equilibrium I depends on the blood-gas partition coefficient 1 of the solvent, and equilibrium II on the tissue-blood partition coefficient (for each tissue group).

This exchange can be summarized by the following equations:

$$
\begin{aligned}
& C_{1} V_{1}+C_{2} V_{2}=w_{1}+w_{2} \\
& w_{1}=C_{1} V_{1} \\
& w_{2}=\lambda C_{1} V_{2}=C_{2} V_{2}
\end{aligned}
$$

where $V_{1}$ and $V_{2}$ are the volumes of the compartments, $w_{1}$ and $w_{2_{0}}$ are the quantities of solvent in the compartments before equilibration, $C_{1}$ and $C_{2}$ are the final concentrations, $w_{1}$ and $w_{2}$ the final quantities of solvent in the compartments after equilibration, and $\lambda$ is the partition coefficient.

(1) The lung tissue-gas partition coefficient is assumed to be the same as the blood-gas partition coefficient (Eger, 1963a).

For equilibrium I:

$$
V_{1}=\text { effective tidal volume }\left(V_{\mathrm{A}}\right) \text { (tidal }
$$
volume minus dead space) + preinspiratory gas volume $(V \mathrm{p})$ (corresponding to the functional residual capacity)

$w_{1_{0}} \quad=$ weight of solvent in $V_{\mathrm{A}}$ inspired at the beginning of $\mathrm{dt}\left(=V_{\mathrm{A}}\right.$. $C^{\prime}$ Insp (2)) + weight of solvent remaining in $V \mathrm{p}$ at the end of the preceding respiratory cycle

$C_{1}(3)$ and $w_{1}=$ concentration and weight of solvent in $V_{1}$ after equilibration

$V_{2} \quad=$ volume of capillary blood exposed to alveolar air during $\mathrm{dt}\left(\mathrm{Q}_{\mathrm{c}}\right)+$ volume of lung tissue 


\begin{tabular}{|c|c|c|}
\hline$w_{2_{0}}$ & & $\begin{array}{l}\text { weight of solvent in a volume } Q_{c} \\
\text { of the mixed venous blood return- } \\
\text { ing to the lungs ( } w_{\mathrm{v}} \text { ) at the end of } \\
\text { the preceding 'circulatory cycle' } \\
\text { (4) + weight of solvent remaining } \\
\text { in the lung tissue at the end of the } \\
\text { preceding respiratory cycle }\end{array}$ \\
\hline$C_{2}$ & $=$ & $\begin{array}{l}\text { concentration of solvent } \\
\text { pulmonary blood and lung tisst } \\
\text { after equilibration }\end{array}$ \\
\hline$w_{2}$ & & $\begin{array}{l}\text { weight of solvent in pulmona } \\
\text { blood }\left(w_{c}\right)+\text { that in lung tissu } \\
\text { after equilibration }\end{array}$ \\
\hline$\lambda$ & $=$ & blood-gas partition coefficient. \\
\hline
\end{tabular}

(2) The concentration of solvent $\left(\mathrm{C}_{\text {Insp }}\right)$ in the ambient air of the exposure chamber $\left(18^{\circ} \mathrm{C}\right.$, relative humidity $50 \%$, pressure $720 \mathrm{mmHg}$ ) was corrected

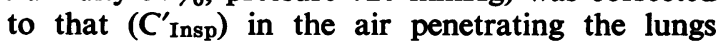
$\left(37^{\circ} \mathrm{C}\right.$, saturated with water vapour) according to the relation:

$$
C_{\text {Insp }}^{\prime}=\frac{720-47}{720-8} \cdot \frac{273+18}{273+37} C_{\text {Insp }}=0.89 C_{\text {Insp. }}
$$

(3) Corresponding to $\mathrm{C}_{\mathrm{Alv}}$ in the figures.

(4) See below.

For equilibrium II (for each tissue group):

$V_{1} \quad=$ volume of blood perfusing the tissue group during $\mathrm{dt}$ (which is a fraction of $\mathrm{Q}_{\mathrm{c}}$ given by the $\%$ of cardiac output perfusing the tissue group, see Table 2).

$\begin{array}{ll}w_{1} & \begin{array}{r}\text { weight of solvent in } V_{1} \text { before } \\ \text { equilibration (which is a frac- } \\ \text { tion of } w_{\mathrm{c}} \text { calculated as above) }\end{array} \\ = & \text { volume of the tissue group } \\ = & \text { weight of solvent in } V_{2} \text { at the } \\ & \text { end of the preceding respira- } \\ V_{2} & \text { tory cycle } \\ w_{2} & \text { respective concentrations and } \\ & \text { weights of solvent in } V_{1} \text { and } \\ & V_{2} \text { after equilibration } \\ = & \text { tissue group-blood partition } \\ & \text { coefficient. }\end{array}$

In this model ventilation is treated as a cyclic process, a volume $\dot{Q}_{c}(=Q / f)$ of blood being exposed to alveolar air during each respiratory cycle. If $Q$ is the blood volume and $Q_{\mathrm{c} 1}$ the blood passing through the lungs during the first respiratory cycle, the time between two passages of $\mathrm{Q}_{\mathrm{c} 1}$ (or the duration of a 'circulatory cycle') corresponds to $Q / Q_{c}(=n)$ respiratory cycles. The computer program equilibrates $Q_{\mathrm{c} 1}$ (arterial) with tissue groups immediately after the former has left the lungs $\left(Q_{c 1}\right.$ is divided into four fractions in proportion to the per cent of cardiac output to each tissue group). Then the four fractions of $Q_{\mathrm{c} 1}$ (venous) are combined when leaving the tissues and queued for $n$ respiratory cycles before the next equilibration with the lungs. Therefore the sum of $w_{1}$ of the four tissue groups will give the value of $w_{\mathrm{v}}, n$ respiratory cycles later. The same is done for $\mathbf{Q}_{\mathrm{c} 2}, \mathbf{Q}_{\mathrm{c} 3}, \ldots \mathrm{Q}_{\mathrm{n}}$ corresponding to the blood passing through the lungs during the second, third ... $n^{\text {th }}$ respiratory cycle. At the $n^{\text {th }}+1$ respiratory cycle, with the beginning of the second 'circulatory cycle', the second equilibrium of $Q_{c 1}$ with alveolar gas occurs.

The assumptions on which such a mathematical model is based have been discussed by several authors (Eger, 1963a; Mapleson, 1963; Kety, 1951; Cowles et al., 1972). The main assumptions are: (a) there is no limitation of diffusion between alveolar gas and pulmonary blood or between peripheral blood and tissue groups, and equilibrium is reached almost instantaneously; (b) alveolar ventilation, rates of blood flow, and other physiological or physical parameters are constant unless stated otherwise; (c) concentration within each compartment, particularly within each tissue group, is uniform; $(d)$ there is no diffusion of solvent between tissue groups; $(e)$ there are neither unventilated alveoli nor arteriovenous shunts; $(f)$ the respiratory quotient is 1 .

Received for publication 20 September 1973.

Accepted for publication 26 November 1973.

All communications should be sent to Dr. J. Fernandez. 